\title{
THE MODEL OF STRENGTHENING THE NATIONAL IDENTITY IN THE CADRE PROCESS OF STUDENT ORGANIZATION
}

\author{
Darda A. Sjam ${ }^{1}$, Dasim Budimansyah ${ }^{2}$, Encep S. Nurdin ${ }^{3}$, Elly Malihah ${ }^{4}$
}

Abstract: This study aims to identify the model of strengthening the national identity through the cadre pattern in the Islamic Student Association organization (HMI). This study applied a qualitative approach with a case study method. Student organizations have a crucial role in providing insight, sense, and spirit of Indonesian nationalism that is wrapped in the frame of Unity in Diversity. One of the challenges faced by a student organization in Indonesia is the ability of this organization to protect its noble goals from certain interests, which can direct the activities to the issues that violate the motto. In this context, cadre in student organizations must strive to foster and strengthen the spirit of nationalism. The presence of a student religious organization provides its uniqueness that is noteworthy to study. Therefore, this study will identify how the concept of student religious organization regeneration, especially the Islamic Student Association. In this article, the researcher views that the cadre of a religious student organization such as the Islamic Student Association has a very unique and strong style of regeneration. It can be observed from the numerous cadres of Islamic Student Association who work in government, non-governmental organizations, and other sectors who are highly open with differences and voice about the importance of togetherness in unity, which is based on the ideology of struggle, i.e., pluralism, democracy, state administration, and law enforcement. The three struggle programs are determinative factors for caring for the National Identity (Unity in Diversity).

Keywords: Islamic Student Association, Cadre, National Identity

JOMSIGN: Journal of Multicultural Studies in Guidance and Counseling Website: http://ejournal.upi.edu/index.php/JOMSIGN

Permalink: https://ejournal.upi.edu/index.php/JOMSIGN/article/view/26413

How to cite (APA): Sjam, D. A., Budimansyah, D., Nurdin, E. S., Malihah, E. (2021). The Model of Strengthening the National Identity in the Cadre Process of Student Organization. JOMSIGN: Journal of Multicultural Studies in Guidance and Counseling, 5(1), 50-57

This is an open-access article distributed under the terms of the Creative Commons Attribution 4.0 International License, which permits unrestricted use, distribution, and reproduction in any medium, provided the original work is properly cited.

\section{INTRODUCTION}

Students as a campus community have the main task of learning such as completing assignments, reading material sources, writing papers, having

\footnotetext{
${ }^{1}$ Universitas Pasundan, Indonesia; darda.abdullah@gmail.com

${ }^{2}$ Universitas Pendidikan Indonesia, Indonesia; budimansyah@upi.edu

${ }^{3}$ Universitas Pendidikan Indonesia, Indonesia; encep.sn@upi.edu

${ }^{4}$ Universitas Pendidikan Indonesia, Indonesia; ellymalihah@yahoo.com
} 
presentations, joining discussions, attending seminars, and other academic activities. Besides the main task, other tasks are heavier and more closely related to the meaning of the students themselves, i.e., as agents of change (Siallagan, 2011). The agent of change that is frequently labelled to students shows the great expectation to bring the nation in a better direction. Therefore, students are young people who have a responsibility for the future of their nation. One of the examples of students' role as the agents of change has been recorded in Indonesia's history in 1998, which succeeded in undermining an authoritarian regime. Despite the abduction, strife, and sacrifice to achieve freedom democratically, the role has still been completed, and generate students as a pillar and vanguard for the Indonesian nation.

Seeing the complex role of them, students need guidance in the form of capacity building and student identity that is manifested in attitudes, behaviors, personalities, and character. Further, that guidance should be able to be a solution to the demoralization of Indonesian society that happens currently to be decreased since students are the nation's assets, as young intellectual candidates for future leaders. One of the activities that can develop capacity and identity building for students is joining the organization (Hasdiansyah, 2017). It is also reinforced by Huang and Chang (2004), which claimed that students will perform thinking skills, communication skills, interpersonal skills, and self-confidence better when they are joining the organization. Therefore, student organizations have a crucial role in constructing the nation's young generation.

The Islamic Student Association (Himpunan Mahasiswa Islam or HMI) is one of the modern organizations. HMI was initiated two years after the Indonesian nation's independence, which had initial ideals as a forum for Islamic student associations in Indonesia (Sitompul, 1997). As a large organization, HMI is part of an organization that conducts training and regeneration for its cadre regularly. The cadres who are expected to bring the leadership relay in the future according to Alfian (1980) are to have the following qualifications: 1) to have reliable leadership qualities; 2) service becomes the basis of work, and the organization as a place to serve for a greater purpose; 3) not solely oriented to power, but rather to the service of others, and power is only a tool of service; 4) someone who has a high need of achievement motive; 5) sensitive to environmental changes, especially those that have a direct influence on him and the organization he joins. 
The cadre process in the HMI organization has a standard starting from Latihan Kader I (Basic Training), Latihan Kader II (Intermediate Training) to Latihan Kader III (Advanced Training). It is perceived from the orientation to be achieved by the organization. HMI is an Islamic Student Association so it is clear that Islamic values are the main domain in its cadre (Azra, 2002). This organization aims at maintaining the integrity of the Republic of Indonesia and attempting to apply the mandate of the 1945 Constitution. In a brief, this organization consistently maintains Pancasila as the national identity of the Indonesian nation.

National identity can be interpreted as a manifestation of cultural values that grow and develop from various aspects of hundreds of tribes' life, which is gathered in one unity of Indonesia into a national culture that is based on Pancasila and the spirit of "Unity in Diversity" as the basis and direction for its development. In other words, the essence of National Identity is the Pancasila itself. The identity of the nation is seen as the embodiment of the nation's noble values contained based on the Indonesian state, Pancasila, which consists of the concepts of religiosity, humanity, nationality, sovereignty, and sociality. Discussions about national identity hide assumptions about the authenticity that are embedded in the fundamentals of a nation. National identity is something that makes us quickly recognize someone's nationality from his speech, behavior, and beliefs. Identity is a kind of public morality that guides the lives of individuals in a nation.

Building the national identity is begun by building the identity of every Indonesian human being as a Pancasila human being. Pancasila as the Indonesian national identity distinguishes it from other nations. The identity of the Indonesian nation is a reflection of the character of the Indonesian Nation. Thus, the character of the nation will be displayed as noble values that are extracted from real life and formulated in a system of values known as Pancasila. The decrease of national identity impact through patterns of community behavior will diminish the state of the nation in various fields. Therefore, the nation can easily be destroyed or colonized by other countries. Currently, numerous efforts are being made to strengthening national identity that is deemed necessary and critical to do such as training in its cadre process. It can be used as a basis and direction in efforts to develop capabilities and attitudes systematically that increase work results, life as stated by Goldstein and Ford (2002), as completed by HMI. Therefore, this study attempted to 
identify the model of strengthening the national identity through the cadre pattern.

\section{METHOD}

This research used a qualitative approach with the case study method. It was conducted by implementing purposive sampling as its sampling technique. Creswell (2007) explained that a case study is a research strategy in which researchers carefully investigate a program, event, activity, process, or group of individuals. The case study used in this research is about the model of strengthening national identity in the process of student cadre organization in the Islamic Student Association in growing the value of national identity.

To conduct the function as the main instrument (key instrument), researchers used three data collection methods, namely: participatory observation, interviews, and documentation studies. In taking the data carried out in two models, namely primary data collection and secondary data. This research was located in Badko HMI of West Java with research subjects totalling 200 respondents consisting of three MOT groups (Master of Training) at the cadre level of the Islamic Student Association.

Analysis of the data used in this study was the Miles and Huberman interactive data analysis model. According to Miles and Huberman (1992), qualitative data analysis is an interactive, continuous, and continuous effort. Data analysis consists of three activities that occur simultaneously, namely: data reduction, data presentation, and concluding/verification.

\section{FINDINGS AND DISCUSSIONS}

Social change is one of the vital elements in the transformation of society that can be marked by changes in composition, structure, function, boundaries, and environment in a social system of society. According to Adamson and Borgos (1984), the main agents of social change are interpreted as mass movements and the resulting conflicts. Moreover, several experts also argue that social movement is one of the main ways to restructure society in a better direction. The presence of HMI as an Islamic organization and struggle in higher education and student affairs requires its cadres to become a new phenomenon in the da'wah instrument of Islamic Organization struggle in society. HMI cadres must be able to guarantee the continuity of the student movement and 
be able to assist the community in facing the adverse effects of dynamic social change. By taking an external basis, HMI positions itself as an organization of struggle that has a role and function in controlling policies and any social changes, which can harm society as well as making efforts for community service to maintain the stability of the state.

The regeneration process of the HMI organization, to sustain the cadre that has political education and good training, should have systematic stages and noble goals (Mukhtar, 2006). HMI has identified itself with the interests of Muslims as a whole, from the beginning of the emergence of the New Order until the middle of the 1970s were still able to compromise with the political policies adopted by the New Order. However, in the late 1970s, the HMI community became relatively more sensitive to the condition of the degradation of the power of the Muslims, especially in the political field and tried to review the social, economic and political realities that had been and are ongoing.

Cadre is a significant issue in its influence on the sustainability of an organization. Hashim (2009) confirmed that "Recruitment refers to the process by which organisations locate and attract potential individuals to fill job vacancies. The ultimate objective is to find and hire the most suitable person to fill job vacancies. To find a suitable person, the organisation will need to determine and outline the job requirements and job incumbent requirements. In most organisations, this responsibility usually is shouldered by the human resource manager".

The Islamic Student Association (HMI) as a cadre organization is expected to be able to become a tool of struggle in transforming ideas and actions towards the formulation of the ideal to be built, i.e., the development of Islamic academician, creators, partisans and are responsible for the creation of a prosperous and just society that is guided by Allah SWT. Therefore, three points should be emphasized to strengthen and provide optimal value for the cadre of HMI. First, the recruitment of cadre candidates. In this case, HMI must determine the priority of recruiting prospective cadres from selected students, namely cadre input that has personal integrity is willing to improve and develop themselves continuously, has a high achievement orientation and leadership potential, and has a commitment to be active in advancing the organization. Second, the cadre process that is implemented is largely determined by the quality of the management as the person in charge of the 
cadre, the manager of the training, the cadre guidelines, the material being communicated, and the facilities used. Third, the environment and atmosphere that are built must be conducive to the development of cadre quality, i.e., an environment that respects individual achievements, encourages enthusiasm for learning and working hard, creates a space for dialogue and individual interaction democratically, and is open to building critical attitudes that generate the futuristic views and create media for stimulating awareness of the social environment.

The implementation of cadre modelling in HMI organizations is categorized as consistent. From the respondents' interview, the researchers obtained the information, which indicated that the process of cadre modelling in the HMI organization was conducted consistently in each period of management. Each cadre in the HMI organization passed several stages to be in the process of being prepared to dedicate.

\section{CONCLUSION AND RECOMMENDATION}

Referring to the results of research and discussion conducted by researchers on the formulation of research problems, the conclusions are as follows:

First, the HMI organization is an organization that has a cadre pattern and concept that is systematically arranged and has guidelines in the care process. The concept of cadre in the HMI is implemented based on the results of Congress in each period. This organization also applies a strong cadre formation pattern, especially in achieving the goals, vision, and mission, i.e., the establishment of Islamic academicians, creators, partisans, and are responsible for the formation of a just and prosperous society that is blessed by Allah SWT. The HMI organization always strengthens and provides optimal value for its cadre. Three points that should be emphasized by this organization are first, recruitment of cadre candidates. In this case, HMI must determine the priority of recruiting prospective cadres from selected students, i.e., cadre input that has personal integrity is willing to improve and develop themselves continuously, has a high achievement orientation and leadership potential, and has a commitment to be active in advancing the organization. Second, the cadre process that is implemented is largely determined by the quality of the management as the person in charge of the cadre, the manager of the training, the cadre guidelines, and the material being communicated as well as the facilities used. Third, the environment and atmosphere that are 
built must be conducive to the development of cadre quality, i.e., an environment that respects individual achievements, encourages enthusiasm for learning and working hard, creates a space for dialogue and individual interaction democratically and is open to building critical attitudes that produce futuristic views and create media for stimulating awareness of the social environment.

Second, the HMI organization applies a gradual cadre model. These stages must always be passed by each cadre to become a great cadre. In every stage of the organization, HMI applies the concept of upholding values to Islam and Indonesia. It is embedded since the cadres pass the recruitment stage and then move to the introduction stage by applying several principles such as the principles of integration, equality, balance, and others. By upholding these principles, each cadre will have a further positive culture of the problems posed by the diversity that occurs in Indonesia. At the stage of forming and developing, HMI cadres apply some training to improve the quality of cadres. Cadre training is conducted with three levels on an ongoing basis. It will make each cadre able to maintain consistency and commitment in applying the vision and mission and objectives of the HMI organization.

Based on the conclusion above, the postulations that the researcher can make are as follows:

1. Strengthening national identity can be completed through the activities of the HMI student organizations

2. One effort to save generations is through cadre or regeneration in organizations

3. The student organization is a vital element in supporting the achievement of educational goals

\section{ACKNOWLEDGEMENTS}

We would like to thank various parties who have supported this research activity. Our gratitude goes to Universitas Pendidikan Indonesia academy community and General and Character Education Program, who have afforded the encouragement and facilities so we can conduct this research. We also would like to thank the Universitas Pasundan who helped the research process so that it proceeded according to plan.

\section{REFERENCES}

Adamson, M., \& Borgos, S. (1984). This Mighty Dream: Social Protest Movements in the United States. Boston: Routledge \& Kegan Paul. 
Alfian (1980). Politik, Kebudayaan, dan Manusia Indonesia. Jakarta: LP3S

Azra, A, (2008). Pendidikan Kewarganegaraan: Demokrasi, Hak Asasi Manusia dan Masyarakat Madani. Jakarta: Kencana.

Creswell, J. W. (2014). Research Design: Qualitative, Quantitative and Mixed Methods Approaches (4th ed.). Thousand Oaks, CA: Sage.

Creswell, J. W. (2007). Second Edition Qualitative \& Research Design (Vol. 1). United States of America: Sage Publications.

Goldstein, I. L \& Ford, J. K. (2002). Training In Organization. Canada: Vicky Knight.

Hadiansyah, Andi. (2017). Peran Kader Himpunan Mahasiswa Islam dalam Membangun Tradisi Ilmiah di dalam Kampus. Jurnal Eksistensi Pendidikan Luar Sekolah (E-Plus) 2 (2).

Hashim, J. (2009). Islamic revival in human resource management practices among selected Islamic organisations in Malaysia. International Journal of Islamic and Middle Eastern Finance and Management, 2(3), 251-267.

Huang, Y. \& Chang, S. 2004. Academic and cocurricular involvement: Their relationship and best combinations for student growth. Journal of College Student Development, 45 (4), 391-406.

Miles, M.B., \& Huberman, A.M., 1992. Qualitative Data Analysis. Translation: Rohidi, T.R. (1992). Jakarta: University of Indonesia Press.

Mukhtar, Sidratahta. (2006). HMI dan Kekuasaan. Jakarta: Prestasi Pustaka.

Siallagan, D.F. 2011. Fungsi dan Peranan Mahasiswa. Bengkulu: Universitas Bengkulu.

Sitompul, Agussalim. (1997). Pemikiran HMI dan Relevansinya dengan Sejarah Perjuangan Bangsa Indonesia. Yogyakarta: Aditya Media

Somantri, G. R. (2010). Jati Diri Bangsa. In the Seminar of Etnopedagogik dan Pengembangan Budaya Sunda. Bandung: Universitas Pendidikan Indonesia. 